\title{
Blended Learning (WA Group dan Kunjungan Siswa) Solusi Pembelajaran Jarak Jauh di SMP Negeri 3 Kalibagor
}

\author{
Blended Learning (WA Group and Student Visits) Solution on Long Distance Learning in \\ SMP Negeri 3 Kalibagor
}

Daryanto

SMP Negeri 3 Kalibagor, Banyumas, Jawa Tengah

\begin{tabular}{l}
\hline \hline ARTICLE INFO \\
\hline Article history: \\
DOI: \\
10.30595/pssh.v1i.79 \\
Submitted: \\
April 12, 2021 \\
Accepted: \\
June 10, 2021 \\
Published: \\
June 14, 2021 \\
\hline
\end{tabular}

\section{Keywords:}

WA Group, home visits, PJJ

\begin{abstract}
During the Covid-19 pandemic, learning at SMP N 3 Kalibagor must continue, but various obstacles arise in distance learning. Limitations of internet quota, feeling lazy and bored with studying alone at home and limited internet coverage in the area around the school are obstacles. The teacher must be able to find the right distance learning solution so that it can serve the learning of all students with all their limitations and problems. Observation and interviews are the right methods for obtaining data from students and teachers. Blended learning between online and offline PJJ is an alternative that can be implemented to overcome PJJ during the Covid pandemic 19 Learning communication with class group WA is used to provide material and assignment information learning. Offline learning activities with visits to students' homes or study groups need to be done to serve students who have problems and limitations. Activities visiting students can provide a spirit of motivation and character education for students. Blended learning by combining WA class groups and student home visits and study groups is an appropriate alternative in distance learning.
\end{abstract}

This work is licensed under a Creative Commons Attribution 4.0 International License.

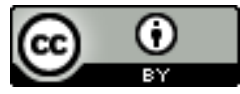

\section{Corresponding Author:}

Daryanto

Guru PPKn SMP Negeri 3 Kalibagor

Jalan Kalianja Petir Kalibagor Banyumas, Jawa Tengah, Indonesia.

Email: soalo11920@gmail.com

\section{PENDAHULUAN}

Wabah covid -19 telah melumpuhkan semua sector kehidupan bermasyarakat berbangsa dan bernegara. Pendidikan sebagai bagian tidak terpisahkan dari sebuah system pembangunan nasional juga terkena imbasnya. Sejak awal Maret 2020, pemerintah melalui kementerian pendidikan nasional telah memerintahkan pada semua lembaga pendidikan untuk mengadakan pembelajaran jarak jauh. Pembelajaran jarak jauh merupakan upaya pemerintah untuk mencegah dan memutus rantai penyebaran covid 19 di dunia pendidikan. Pembatasan sosial/menjaga jarak yang dilakukan untuk mencegah penularan Covid-19 agar tidak menyebar luas di Negara Indonesia. Hasil keputusan dari menteri pendidikan bahwa seluruh kegiatan pembelajaran baik di sekolah maupun perguruan tinggi dilaksanakan di rumah masing-masing melalui aplikasi yang tersedia.

Pembelajaran jarak jauh yang selanjutnya disebut PJJ adalah pendidikan yang peserta didiknya terpisah dari pendidik dan pembelajarannya menggunakan berbagai sumber belajar melalui teknologi informasi dan komunikasi, dan media lain [1]. Pembelajaran jarak jauh memiliki tantangan tersendiri yang harus dihadapi. Sehingga kreativitas para pengajar sangat dibutuhkan dalam pelaksanaannya sehingga mereka harus keluar dari gaya konvensional. Guru adalah pendidik profesional dengan tugas utama mendidik, mengajar, membimbing, mengarahkan, melatih, menilai, dan mengevaluasi peserta didik pada pendidikan anak usia dini jalur pendidikan 
formal, pendidikan dasar, dan pendidikan menengah. Guru juga dituntut harus lebih inovatif dalam menyiapkan materi dan mekanisme pembelajaran. Guru adalah pendidik profesional dengan tugas utama mendidik, mengajar, membimbing, mengarahkan, melatih, menilai, dan mengevaluasi peserta didik pada pendidikan anak usia dini jalur pendidikan formal, pendidikan dasar, dan pendidikan menengah.guru harus pandai memanfaatkan seluruh potensi teknologi yang ada untuk membantu pelaksanaan pembelajaran [2]. Di era digital seperti sekarang, secara umum guru harus memiliki kemampuan untuk menggunakan berbagai aplikasi yang ada di di android. Daring ( dalam Jaringan ) / online dapat didefinisikan sebagai sebuah bentuk teknologi informasi yang diterapkan di bidang pendidikan dalam bentuk dunia maya. Pembelajaran daring adalah bentuk pembelajaran jarak jauh yang memanfaatkan teknologi telekomunikasi dan informasi, misalnya internet, CD-ROOM [3].

WhatsApp merupakan aplikasi berbasis internet yang memungkinkan setiap penggunanya dapat saling berbagi berbagai macam konten sesuai dengan fitur pendukungnya. WhatsApp jugamemiliki berbagai fitur yang dapat digunakan untuk berkomunikasi dengan bantuan layanan internet [4]. WhatsApp merupakan media sosial paling populer yang dapat digunakan sebagai media komunikasi. Umumnya para pengguna WA menyebutkan alasan memilih aplikasi ini adalah karena tersedianya berbagai kemudahan yang ada didalamnya disamping tidak mengeluarkan biaya alias gratis[5].

Pembelajaran daring tentunya akan membantu pengajar maupun siswa dalam melakukan pembelajaran jarak jauh. Pembelajaran daring yang dilakukan oleh guru dan siswa dalam kenyatanya banyak menemuai kendala , antara lain keterbatasan kuota internet yang dimiliki oleh guru dan siswa dan terbatasnya jangkauan internet di suatu wilayah, tidak semua wilayah dapat terjangkau oleh layanan internet. Kekurangan yang paling menonjol adalah pengajar dan siswa tidak terbiasa dengan pembelajaran daring. Apalagi dalam pembelajaran daring menggunakan aplikasi melalui smarthphone ataupun laptop karena tidak semua peserta didik bisa menggunakannya

Saat ini guru dan siswa SMP N 3 Kalbagor, 90 persen telah memiliki dan mnguasai berbagai aplikasi yang tersedia di Android. WA merupakan aplikasi yang sudah akrab dengan siswa dan guru di SMP N 3 Kalibagor, semua info dari pihak sekolah disampaikan menggunakan aplikasi WA. Pembelajaran jarak jauh dengan online secara keseluruhan dalam masa pandemic dianggap efektif untuk melakukan sosial distancing, untuk mencegah penyebaran dan penularan virus covid 19 .

Dari latar belakang diatas maka peneliti menyajikan masalah, solusi apakah yang tepat untuk melakukan pembelajaran jarak jauh ? apakah blended merupakan solusi tepat untuk pembelajaran jarak jauh ?.

Tujuan penelitian ini adalah mencari solusi tepat untuk pembelajaran jarak jauh, dan dan apakah blended learning efektif mengatasi pembelajaran jarak jauh yang dapat diterima dan dilaksanakan oleh guru dan siswa. Dari paparan rmasalah dan tujuan penelitian ini, penulis tertarik untuk mengetahui pendekatan pembelajaran apakah yang tepat untuk pembelajaran jarak jauh di masa pandemic covid - 19

\section{METODE PENELITIAN}

Jenis penelitian yang digunakan dalam penelitian ini adalah metode deskriptif kualitatif yaitu pendekatan atau penelusuran untuk mengeksplorasi dan memahami suatu gejala sentral. Hasil penelitian kualitatif di ranah pendidikan bersifat deskriptif. Tujuan penelitian kualitatif adalah memahami pandangan individu, mencaritemukan dan menjelaskan proses, dan menggali informasi mendalam tentang subjek atau latar penelitian yang terbatas [6]. Subjek penelitian yang digunakan dalam penelitian ini adalah guru di SMP N 3 Kalibagor. Dalam memilih subjek penelitian, peneliti menggunakan teknik sampling purposive. Sampling purposive merupakan "teknik penentuan sampel dengan pertimbangan tertentu" [7]. Pemilihan subjek tersebut dilatarbelakangi karena tujuan dari penelitian ini yaitu bagaimana pembelajaran jarak jauh berjalan efektif dan solusi apa yang tepat untuk melakukan pembelajaran jarak jauh.

. Teknik pengumpulan data merupakan suatu kegiatan yang dilakukan peneliti guna mendapatkan data-data yang digunakan dalam penelitian. Teknik pengumpulan data yang digunakan dalam penelitian ini adalah berupa wawancara, angket atau kuesioner, dan dokumentasi. Jenis wawancara yang digunakan dalam penelitian ini berupa wawancara semiterstruktur. Jenis angket yang digunakan dalam penelitian ini adalah angket terbuka. Angket terbuka merupakan angket yang berisi pertanyaan atau pernyataan yang dapat diisi bebas oleh responden. Dokumen merupakan catatan peristiwa yang sudah berlalu. Dokumen bisa berbentuk tulisan, gambar, atau karya-karya monumental dari seseorang [8]. Teknik analisis data yang digunakan peneliti merupakan teknik analisis Miles and Huberman, yaitu mengemukakan bahwa aktivitas dalam analisis data kualitatif dilakukan secara interaktif dan berlangsung secara terus menerus sampai tuntas, sehingga datanya sudah jenuh [7].

Terdapat tiga aktivitas dalam analisis data yaitu, data reduction, data display, dan conclusion drawing/verivication. Pada tahap data reduction data yang diperoleh di lapangan jumlahnya cukup banyak, untuk itu perlu dicatat secara teliti dan rinci. Mereduksi data berarti merangkum, memilih hal-hal yang pokok, memfokuskan pada hal-hal yang penting, dicari tema dan polanya dan membuang yang tidak perlu. Data yang telah direduksi akan memberikan gambaran yang lebih jelas, dan mempermudah peneliti untuk melakukan pengumpulan data selanjutnya, dan mencarinya bila diperlukan [7]. Pada tahap data display bertujuan agar memudahkan peneliti untuk memahami apa yang terjadi, serta dapat merencanakan langkah selanjutnya berdasarkan apa yang telah dipahami 
tersebut. Tahap yang terakhir conclusion drawing/verivication dalam penelitian kualitatif mungkin dapat menjawab rumusan masalah yang dirumuskan di awal atau juga mungkin tidak. Hal tersebut terjadi karena penelitian kualitatif masih bersifat sementara dan akan berkembang setelah penelitian berada di lapangan.

Prosedur penelitian yang digunakan dalam penelitian ini terbagi kedalam tiga tahapan yaitu tahap pralapangan, tahap pekerjaan lapangan, dan tahap analisis data. Tahap pra-lapangan, pada tahap ini peneliti menyusun rancangan penelitian berupa pemahaman mengenai metode dan teknik dalam penelitian. Memilih lapangan penelitian, menjajaki dan menilai lapangan berupa orientasi lapangan dengan maksud dan tujuan supaya peneliti berusaha mengenal segala unsur lingkungan sosial, fisik, dan keadaan alam serta pengenalan lapangan juga dimaksudkan untuk menilai keadaan, situasi, latar, dan konteksnya apakah terdapat kesesuaian dengan masalah, menyiapkan perlengkapan penelitian berupa perlengkapan yang dibutuhkan atau digunakan dalam penelitian seperti izin penelitian, alat tulis dan perlengkapan lainnya dalam menunjang penelitian.

Tahap pekerjaan lapangan, pada tahap ini peneliti memahami latar penelitian terlebih dahulu. Peneliti perlu menyiapkan diri untuk mulai melakukan penelitian guna mendapatkan data atau informasi yang diperlukan dalam penelitian. Data yang diperoleh berasal dari angket dan wawancara yang dilakukan kepada siswa dan guru SMP N 3 Kalibagor di tempat penelitian adalah SMP N 3 Kalibagor. Peneliti membuat sebuah analisis untuk mendapatkan hasil yang lebih mendalam mengenai pembelajaran jarak jauh dan blended learning sebagai salah satu solusi pembelajaran jarak jauh. Setelah data tersebut didapatkan, peneliti menyusun data tersebut secara deskriptif dan mendalam agar data yang sudah didapatkan dapat dipelajari dengan baik. Tahap analisis data, dalam penelitian kualitatif data yang didapatkan berasal dari berbagai sumber data yang dikumpulkan melalui berbagai macam teknik pengumpulan data, serta dilakukan secara terus menerus sampai datanya jenuh. Analisis data yang dilakukan peneliti yaitu mengolah data yang telah dikumpulkan dan didapatkan selama di lapangan baik berupa informan maupun dokumen-dokumen pada tahap sebelumnya, kemudian disusun menjadi sebuah penelitian..

\section{HASIL PENELITIAN}

Berdasarkan hasil penelitian didapat dari angket terbuka dan wawancara semi struktur yang dilakukan secara daring. Angket disebarkan secara daring melalui google form, sedangkan untuk wawancara dilakukan menggunakan whatsapp. Adapun hasil penelitian yang diperoleh dalam penelitian ini adalah sebagai berikut.

\section{Angket}

Angket disebarkan kepada seluruh guru di SMP N 3 Kalibagor . Angket yang digunakan dalam penelitian ini merupakan jenis angket terbuka, dimana angket terbuka merupakan angket yang jawabannya diisi oleh responden. Penggunaan angket ini bertujuan untuk mendapatkan informasi berupa pelaksanaan proses pembelajaran secara jarak jauh selama masa pandemic covid-19 serta blended learning sebagai salah satu solusi dalam melaksanakan proses pembelajaran jarak jauh selama masa pandemi covid 19. Berikut ini merupakan jawaban yang diberikan oleh responden.

a. Apakah selama pandemi covid -19 Bapak/Ibu menerapkan proses pembelajaran daring atau online? Jika iya bagaimana prosesdur pelaksanaan proses pembelajaran daring yang telah dilaksanakan oleh Bapak/Ibu selama pandemi covid-19?

"Iya saya melakukan pembelajaran daring. Pelaksanaanya setiap guru maple membentuk grup WA kelas untuk memudahkan memberi materi pembelajaran dan informasi yang disampaikan kepada siswa." ( S Guru IPS kelas 8)

b. Adakah faktor yang mendukung guru dalam kegiatan belajar mengajar selama pandemi covid-19? Sebutkan faktor pendukung tersebut!

"Ada, komputer, hp, kuota, televisi." ( S Guru mata pelajaran IPS kelas 8 )“Handphone android dan kuota" ( M Guru IPS kelas 9)

c. Adakah faktor yang menghambat guru dalam kegiatan belajar mengajar selama pandemi jarak jauh? Sebutkan faktor penghambat tersebut!

Tidak semua anak memiliki gadget dan tidak semua wilayah memiliki jaringan internet, kadang anak juga malas untuk merespond WA dari guru. Orang tua siswa tidak dapat melakukan pendampingan secara penuh dalam pembelajaran siswa di rumah

2.Wawancara

Wawancara yang digunakan dalam penelitian ini adalah jenis wawancara semi terstruktur terhadap dua responden utama yaitu guru IPS kelas 8 dan guru PPKn kelas 8 SMP N 3 kalibagor. Wawancara dilakukan dengan tujuan untuk memperdalam data yang diperoleh dari angket. Adapun hasil wawancara yang telah dilakukan kepada dua responden adalah sebagai berikut.

a. Apakah selama pandemi covid-19 Bapak/Ibu menerapkan proses pembelajaran daring online ? Jika iya bagaimana prosedur pelaksanaan proses pembelajaran daring yang telah dilaksanakan oleh Bapak/Ibu selama pandemi covid -19 ?

"Ya selama pandemi menerapkan pembelajaran daring. Prosedur yang dilakukan melalui tata muka melalui Zoom meeting atau google meetdalam beberapa materi pembelajaran yang memerlukan hal 
tersebut, misalnya dalam pembelajaran matematika. Hal tersebut dilakukan karena guru tidak bisa hanya menuliskan materi pembelajaran tersebut di catatan atau lewat tulisan. Penggunaan whatsapp sebagai media penghubung antara guru dan peserta didik. Lewat grup whtasapp untuk memberikan tugas dan mengumpulkan tugas. .." ( J Guru PPKn Kelas 8)

b. Adakah kendala dalam melakukan pembelajaran on line / jarak jauh?

Banyak kendala yang ditemui oleh guru terutama keterbatasan kuota dan sarana jaringan yang terbatas serta rendahnya respon siswa dalam menyambut pembelajaran dari guru

c. Adakah faktor yang menghambat guru dalam kegiatan belajar mengajar selama pandemic covid -19 ? Sebutkan faktor penghambat tersebut!

"Faktor yang menghambat dalam proses pembelajaran daring adalah pertama belum semua peserta didik memiliiki handphone pribadi,. Faktor yang kedua adalah peserta didik yang malas meskipun peserta didik tersebut memiliki handphone sendiri atau tidak sesuai dengan aturan yang ditetapkan, yang ketiga terbatasnya jaringan internet yang tidak diterima oleh siswa”( J guru PPKn kelas 8)

d. Apakah anda pernah melakukan kunjungan kerumah siswa untuk memberikan pembelajaran dan tugas ? Apa pendapat anda dengan kunjungan anda ke rumah siswa?

Ya Pernah, saya merasa senang karena dapat bertatap muka dengan siswa dan dapat melakukan pembelajaran sekaligus memeri motivasi dan tugas untuk di kerjakan oleh siswa. ( S Guru IPS Kelas 8 )

e. Apakah bapak/ibu guru kalian pernah mengunjungi rumah kalian ? apa yang dilakukan oleh bapak/ibu guru kalian?

Pernah, bapak ibu guru menyampaikan informasi materi pembelajaran, memberi semangat dan memberi tugas untuk dikerjakan dan dikumpulkan kembali ketika bapak/ibu guru kembali melakukan kunjungan ke rumah. ( siswa kelas 9 A ).

f. Bagaimana perasaan kalian dengan kedatangan guru kalian ke rumah kalian ?

Saya merasa senang dan semangat untuk belajar karena bertemu dengan bapak dan ibu guru dan mendapatkan materi serta motivasi dan pengarahan dari bapak / ibu guru ( Siswa kelas 8 A )

'Berdasarkan hasil penelitian dengan metode kualitatif deskriptif melalui teknik pengumpulan data berupa angket dan wawancara yang telah dilakukan pada guru di SMP N 3 Kalibagor, tentang proses pembelajaran dalam jaringan (daring) serta solusi tepat dalam pembelajaran jarak jauh di masa pandemi covid-19 dapat ditarik kesimpulan bahwa, pandemi covid- 19 sangat berdampak pada dunia pendidikan. Pandemi ini mengakibatkan proses pembelajaran menjadi sangat terganggu, proses pembelajaran yang biasanya dilaksanakan dengan tatap muka langsung antara guru dan siswa di kelas selama pandemi pembelajaran berubah menjadi pembelajaran daring.

Guru mengungkapkan bahwa untuk anak SMP pembelajaran daring masih banyak kendalanya. Keikutsertaan siswa dalam pembelajaran juga tidak mencapai $100 \%$ dalam pembelajaran daring. Ada beberapa siswa yang bahkan tidak mengikuti pembelajaran sama sekali dari awal hingga akhir, sehingga guru merasa bingung dalam proses penilaian peserta didik tersebut. Pembelajaran daring yang dilaksanakan oleh guru menggunakan whatsapp yang digunakan sebagai media guru dalam menyampaikan materi atau mengirimkan tugas kepada siswa [9], juga mengungkapkan bahwa belajar daring dapat menggunakan teknologi digital, namun yang pasti harus dilakukan adalah pemberian tugas melalui pemantauan pendampingan oleh guru melalui whatsapp grup sehingga anak betul-betul belajar. Guru juga harus berkoordinasi dengan orang tua, bisa melalui kunjungan ke rurmah siswa dengan membentuk kelompok belajar untuk memastikan adanya interaksi antara guru dengan orang tua.

Pembelajaran daring membawa dampak kepada siswa, dampak yang dialami oleh siswa yaitu mereka merasa sangat jenuh dan bosan akan pembelajaran. Semangat dan antusias yang ditunjukkan oleh siswa semakin harinya semakin menurun. Penilaian yang diberikan guru dalam pembelajaran daring nilai juga diberikan langsung ketika siswa mengumpulkan tugasnya dan semua mata pelajaran juga memiliki penilaian yang sama. Pembelajaran daring yang dilakukan untuk anak dirasa kurana efektif, jika dipersentasekan keefektifannya hanya sekitar $30 \%$.

Dengan adanya metode pembelajaran jarah jauh membuat para guru perlu waktu untuk beradaptasi dan mereka menghadapi perubahan baru yang secara tidak langsung akan mempengaruhi kualitas hasil belajar [10]. Faktor penghambat tersebut diantaranya belum semua peserta didik memiliki handphone. Faktor yang selanjutnya adalah rasa malas siswa pada saat mengerjakan tugas, mekipun sudah didukung dengan fasilitas yang menunjang pembelajaran. Faktor yang selanjutnya adalah masih banyak orang tua yang bekerja sehingga tidak dapat sepenuhnya membimbing siswa dalam pembelajaran. Ada beberapa cara untuk mengatasi hambatan tersebut, diantaranya adalah memberikan informasi di awal sebelum pembelajaran dilaksanakan agar pada saat pembelajaran semuanya sudah siap mengikuti pembelajaran. Selanjutnya adalah melakukan kerjasama dengan komite kelas terkait siswa yang belum memiliki handphone untuk dapat menanyakan kepada teman yang jarak rumahnya dekat agar dapat sama-sama mengikuti pembelajaran. .

Blended learning adalah sebuah kemudahan pembelajaran yang menggabungkan berbagai cara penyampaian, model pengajaran, dan gaya pembelajaran, memperkenalkan berbagai pilihan media dialog antara fasilitator dengan orang yang mendapat pengajaran. Blended learning juga sebagai sebuah kombinasi pengajaran langsung (face-toface) dan pengajaran online, tapi lebih daripada itu sebagai elemen dari interaksi sosial. Blended learning 
merupakan suatu sistem belajar yang memadukan antara belajar secara face to face (bertatap muka/klasikal) dengan belajar secara online (melalui penggunaan fasilitas/media internet) [11]. Berdasarkan paparan para ahli diatas, dapat didefinisikan blenden learning merupakan sebuah strategi belajar mengajar yang bertujuan untuk mencapai tujuan pembelajaran dengan cara memadukan pembelajaran berbasis kelas/ tatap muka dengan pembelajaran berbasis teknologi dan informasi yang dilakukan secaran daring. Manfaat dari penggunaan e-learning dan juga blended learning dalam dunia pendidikan saat ini adalah e-learning memberikan fleksibilitas dalam memilih waktu dan tempat untuk mengakses. Dengan adanya Blended Learning pembelajaran dapat dilakukan dimana saja dan kapan saja menggunakan internet.. Antara guru dan siswa dapat memberikan feedback baik berupa pertanyaan dan saran secara realtime. Sehingga diskusi serta tanya jawab antara dosen dan mahasiswa tidak hanya berlangsung di jam pelajaran namun juga dapat berlangsung di luar jam pelajaran. Tentunya proses belajar mengajar menjadi lebih efisien dan lebih efektif karena komunikasi dan interaksi antara guru dan siswa dapat terus terjadi bukan hanya saat jam pelajaran .

Blended learning (penggabungan pembelajaran) dengan menggunakan WA grup dan kunjungan ke rumah siswa dianggap efektif untuk mengatasi berbagaiu kendala dalam pembelajaran jarak jauh. WA grup kelas dapat di gunakan untuk menyampaikan informasi dari guru kepada siswa. Kunjungan kerumah menjadi sarana guru untuk bertemu, memberi motivasi dan membangun karakter siswa di rumah. Kunjungan rumah bisa bermakna dalam upaya mendeteksi kondisi keluarga dalam kaitannya dengan permasalahan individu atau siswa yang menjadi tanggung jawab pembimbing atau konselor dalam pelayanan BK [12]. Kunjungan rumah bertujuan untuk mengenal lebih dekat lingkungan hidup siswa sehari hari. Secara khusus tujuan kunjungan rumah berkenaan dengan fungsi bimbingan.Misalnya kaitannya dengan fungsi pemahaman,kunjungan rumah bertujuan untuk lebih memahami kondisi siswa, kondisi rumah dan kondisi keluarga [14]. Seringkali orang tua siswa kurang tahu tentang perkembangan anaknya di sekolah, oleh karena itu kunjungan rumah juga dilakukan untuk menyampaikan pada orang tua mengenai permasalahan yang dihadapi anaknya. Ketika orang tua sudah mengetahui informasi, diharapkan terbangun komitmen yang sama antara pihak sekolah dengan orang tua untuk menangani masalah anaknya.

\section{KESIMPULAN}

Dari hasil penelitian dan pembahasan dapat peneliti simpulkan bahwa di masa covid 19 ini perlu ada solusi pembelajaran jarak jauh yang tepat dengan tetap memperhatikan dan mematuhi protokol kesehatan yang telah ditetapkan oleh pemerintah. Blended learning dengan menggabungkan WA grup mata pelajaran dengan kunjungan ke rumah atau kelompok kecil belajar dengan tetap memperhatikan protokol kesehatan yang telah ditetapkan oleh pemerintah merupakan cara yang tepat untuk melakukan pembelajaran jarak jauh di masa covid 19. Blended learning akan mampu memberi bimbingan belajar dan pendampingan belajar siswa di rumah. Pembentukan karakter dan motivasi belajar siswa dapat dilakukan dengan blended learning. Blended learning dapat mengatasi kendala kendala yang dihadapi dalam pembelajaran jarak jauh secara online murni.

\section{DAFTAR PUSTAKA}

[1] Kementerian Pendidikan dan Kebudayaan, 2018, Peraturan Menteri Pendidikan dan Kebudayaan Republik Indonesia Nomor 24 Tahun 2012 tentang Penyelenggaraan Pendidikan Jarak Jauh Pada Pendidikan Tinggi,Jakarta

[2] Kementerian Pendidikan dan Kebudayaan, 2018, Peraturan Menteri Pendidikan dan Kebudayaan Republik Indonesia Nomor15 Tahun 2018 Tentang Pemenuhan Beban Kerja Guru, Kepala Sekolah, dan Pengawas Sekolah, Jakarta

[3] Molinda, M. 2005. Instructional Technology and Media for Learning New Jersey Colombus, Ohio

[4] Jumiatmoko. (2016). Whatsapp Messenger Dalam Tinjauan Manfaat Dan Adab. Wahana Akademika, 3(1), 5166. https://doi.org/10.21580/wa.v3i1.872

[5] Pranajaya, \& Hendra Wicaksono. (2017). Pemanfaatan Aplikasi WhatsApp (WA) Di Kalangan Pelajar (Studi kasus Di MTs Al Muddatsiriyah dan MTs jakarta Pusat). Prosiding SNaPP2017 Sosial, Ekonomi, Dan Humaniora, Vol 7, No.1, 98-109. Diakses dari http://proceeding.unisba.ac.id/index.php/so sial/article/view/808

[6] Putra, N. (2013). Metode Penelitian Kualitatif Pendidikan. Rajawali Pers

[7] Sugiyono. (2015). Metode Penelitian Pendidikan (Pendekatan Kuantitatif, Kualitatif, dan R\&D. CV Alfabeta

[8] Sugiyono. (2014). Memahami Penelitian Kualitatif. CV Alfabeta

[9] Dewi, W. A. F. (2020). Dampak Covid-19 Terhadap Implementasi Pembelajaran Daring Di Sekolah Dasar. Edukatif: Jurnal Ilmu Pendidikan

[10] Purwanto, A., Pramono, R., Asbari, M., Hyun, C. C., Wijayanti, L. M., \& Putri, R. S. (2020). Studi Eksploratif Dampak Pandemi COVID-19 Terhadap Proses Pembelajaran Online di Sekolah Dasar. EduPsyCouns: "Journal of Education, Psychology and Counseling 
[11] Ratna Sari, Annisa. (2013). Strategi Blended Learning Untuk Peningkatan Kemandirian Belajar Dan Kemampuan Critical Thinking Mahasiswa Di Era Digital. Jurnal Pendidikan Akuntansi Indonesia, Vol. XI, No. 2, Tahun 2013

[12] Tohirin, ( 2007 ) Bimbingan dan Konseling di Sekolah dan Madrasah Berbasis Integrasi, Jakarta: PT Raja Grafindo Persada,

[13] Tohirin. (2011). Metode Penelitian Kualtatif dalam bimbingan dan konseling. Jakarta: Raja Grafindo Persada 